\title{
JENIS ANASTESI DENGAN KEJADIAN HIPOTERMI DI RUANG PEMULIHAN RSUD BANYUMAS
}

\author{
Khamid Arif ${ }^{1}$, Etlidawati² \\ ${ }^{1,2}$ Fakultas Ilmu Kesehatan Program Studi Sarjana Keperawatan \\ Universitas Muhammadiyah Purwokerto 2020 \\ Dusun II, Sokaraja Kulon, Kec. Sokaraja, Kabupaten Banyumas, Jawa Tengah 53181 \\ khamidarif@gmail.com
}

\begin{abstract}
Abstrak
Kasus yang sering terjadi setelah pembedaan di ruang pemulihan salah satunya adalah hipotermi. Salah satu penyebab terjadinya hipotermi pasca operasi adalah jenis anastesi yang digunakan. Tujuan penelitian untuk mengetahui hubungan jenis anastesi dengan kejadian hipotermi. Desain penelitian menggunakan korelasional dengan pendekatan cross sectional. Populasi seluruh pasien post operasi di ruang Pemulihan RSUD Banyumas selama 3 bulan terakhir sebanyak 500 pasien. Besar sampel 83 pasien dengan menggunakan teknik sampling consecutive sampling. Instrumen penelitian yang digunakan yaitu lembar observasi untuk mencatat jenis anastesi dan suhu tubuh. Analisis data menggunakan uji chi square. Hasil penelitian didapatkan Pasien sebagian besar responden berumur 36-46 tahun sebanyak 51 responden $(61,4 \%)$, laki-laki sebanyak 52 responden $(62,7 \%)$ dan pendidikan SMA/SMK sebanyak 39 responden $(47,0 \%)$. Responden mendapatkan anastesi general sebanyak 58 responden $(69,9 \%)$ dan hipotermi sebanyak 60 responden $(72,3 \%)$. Hasil uji statustik didapatkan nilai $\mathrm{p}=0,000$ yang menunjukkan ada hubungan jenis anastesi dengan kejadian hipotermi di Ruang Pemulihan RSUD Banyumas. Jenis anastesi yang digunakan dapat menentukan terjadinya perubahan suhu tubuh yaitu hipotermi.
\end{abstract}

Kata Kunci: Anastesi, Hipotermi, Ruang Pemulihan

\begin{abstract}
Cases that often occur after the distinction in the recovery room one of them is hypothermy. One of the causes of postoperative hypothermy is the type of anaesthetic used. The purpose of the study was to find out the relationship of anaesthetic type to the incidence of hypothermic. Research design uses correlational with cross sectional approaches. The population of all postoperative patients in the Recovery Room of Banyumas Hospital over the past 3 months as many as 500 patients. A large sample of 83 patients using consecutive sampling techniques. The research instrument used is an observation sheet to record the type of anaesthetic and body temperature. Data analysis using the chi square test. Patients mostly respondents aged 36-46 years as many as 51 respondents (61.4\%), men as many as 52 respondents (62.7\%) and high school / vocational education as many as 39 respondents (47.0\%). Respondents received general anaesthetics of 58 respondents (69.9\%) and hypothermi as many as 60 respondents $(72.3 \%)$. Statustic test results obtained a value of $p=0.000$ which showed there was a relationship of anaesthetic type with the incidence of hypothermi in the Recovery Room of Banyumas Hospital. The type of anaesthetic used can determine the occurrence of changes in body temperature, namely hypothermy.
\end{abstract}

Keywords: anesthesia, hypothermia, recovery room

Corresponding author:

Khamid Arif

khamidarif@gmail.com 


\section{PENDAHULUAN}

Pada tahun 2013 hasil survai WHO menunjukkan bahwa jumlah pasien dengan tindakan operasi terjai peningkatan. Peningkatan terjadi dari tahun 2011-2021, data menunjukkan 140 juta-148 juta pasien. Pada tahun 2012 operasi di Indonesia sebanyak 1,2 juta jiwa serta $32 \%$ pasien dengan tindakan laparatomi (Kemenkes RI, 2013). Sedangkan tindakan operasi pada tahun 2018 di RSUD Banyumas sebanyak 2887 (Data RSUD Banyumas, 2019).

Pasien post operasi kemudian dilakukan perawatan di ruang pemulihan serta dilakukan pemindahan pasien ke ruang rawat inap bedah (Rahmayati, 2017). Perawat memiliki peran penting dalam mengembalikan kondisi pasien seperti sebelum dilakukan operasi selama di ruang pemulihan. Selama proses pemulihan perawat selalu melakukan pengontroloan terhadap kondisi pasie, dengan tujuan untuk menghindari komplikasi (Smeltzer \& Bare, 2012).

Kasus yang sering terjadi post pembedaan di ruang pemulihan salah satunya adalah hipotermi. Hipotermi ini disebabkan karena tindakan anastesi (Wiryana et, 2017). Kejadian hipotermia pasca operasi di Ruang Pemulihan di Universitas Gondar Rumah Sakit Ethiopia adalah 30,72\%. Dari jumlah hipotermi sebanyak $30(27,96 \%)$ ringan dan $43(34,44 \%)$ sedang. Pasien bedah dengan anestesi umum hipotermia lebih beresiko dibandingkan dengan anestesi spinal (Abdissa et. al., 2014).

Hasil penelitian Harahap (2014) menunjukkan bahwa kejadian hipotermia setelah pemberian anestesi pasien geriatri ada $113(87,6 \%)$ tahun 2011-2012 di Rumah Sakit Dr. Hasan Sadikin Bandung. Sedangkan kejadian hipotermi di Ruang Pemulihan RSUD Banyumas tahun 2018 post operasi sebesar $45 \%$ (Data RSUD Banyumas, 2019).

Hipotermi pada pasien post operasi jika tidak ditangani secara tepat dan cepat dapat menyebabkan berbagai gangguan / komplikasi pada pasien itu sendiri bahkan menyebabkan kematian. Menurut Yuwono (2013) kondisi suhu tubuh pasien memiliki peran penting dalam menentukan terjadinya infeksi pada daerah operasi. Pasien yang mengalami hipotermia akan merusak fungsi imun yang nantinya menyebabkan vasokonstriksi kulit dan mengurangi aliran darah ke tempat operasi, yang nantinya meningkatkan risiko infeksi pada daerah operasi.

Harahap dkk. (2014) dalam hasil penelitiannya menunjukkan bahwa pasien dengan hipotermia (113,6 menit) di ruang pemulihan mendapatkan perawatan lebih lama dibandingkan pasien yang tidak hipotermia (75,6 menit). Penelitian Hanifa (2017) menunjukkan bahwa hipotermi terjadi 5-65\% dengan jenis anastesi general. Suhu ruangan yang ada di kamar operasi adalah $18^{\circ} \mathrm{C}$, sehingga dapat memicu pasien mengalami hipotermi.

Berdasarkan permasalahan tersebut maka perlu dilakukan penelitian dengan judul "Hubungan Jenis Anastesi dengan Kejadian Hipotermi di Ruang Pemulihan RSUD Banyumas".

\section{METODE PENELITIAN}

Metode penelitian kuantitatif dengan desaian penelitian deskripsi korelasional dengan pendekatan cross sectional. Populasi adalah pasien post operasi di Ruang Pemulihan RSUD Banyumas selama tiga bulan terakhir (Februari-Maret 2019) sebanyak 500 pasien. Penentuan sampel dengan teknik consecutive sampling sebanyak 83 pasien. Kriteria pasien yaitu; a. Kriteria inklusi : Pasien diatas usia $>18$ tahun, Pasien bersedia menjadi responden, Pasien dengan jenis anastesi general dan regional; b. Kriteria eksklusi : Pasien yang mengalami penurunan kesadaran, Pasien dengan gangguan kejiwaan. Instrumen yang digunakan untuk mengukur suhu pasien post operasi menggunakan termometer digital dan dicatat di lembar observasi. Uji analisis menggunakan uji chi square. 


\section{HASIL}

Tabel 1 Karakteristik Responden di Ruang Pemulihan RSUD Banyumas.

\begin{tabular}{lcc}
\hline Karakteristik responden & Frekuensi & Persentasi (\%) \\
\hline Umur & & \\
25-35 tahun & 18 & 21.7 \\
36-46 tahun & 51 & 61.4 \\
$>$ 47 tahun & 14 & 16.9 \\
Jenis kelamin & & \\
Laki-laki & 52 & 62.7 \\
Perempuan & 31 & 37.3 \\
Pendidikan & & \\
SD & 5 & 6.0 \\
SMP & 27 & 32.5 \\
SMA/SMK & 39 & 47.0 \\
D3 & 9 & 10.8 \\
S1 & 3 & 3.6 \\
\hline Total & 83 & 100 \\
\hline
\end{tabular}

Tabel 2 Jenis Anastesi di Ruang Pemulihan RSUD Banyumas.

\begin{tabular}{lcc}
\hline Anastesi & Frekuensi & Persentase (\%) \\
\hline General & 58 & 69.9 \\
Regional & 25 & 30.1 \\
\hline Total & 83 & 100 \\
\hline
\end{tabular}

Tabel 3 Kejadian Hipotermi di Ruang Pemulihan RSUD Banyumas.

\begin{tabular}{lcc}
\hline Hipotermi & Frekuensi & Persentase $(\%)$ \\
\hline Ya & 60 & 72.3 \\
Tidak & 23 & 27.7 \\
\hline Total & 83 & 100 \\
\hline
\end{tabular}

Tabel 4 Hubungan Jenis Anastesi dengan Kejadian Hipotermi di Ruang Pemulihan RSUD Banyumas.

\begin{tabular}{|c|c|c|c|c|c|c|c|}
\hline \multirow{3}{*}{ Jenis anastesi } & \multicolumn{4}{|c|}{ Kejadian hipotermi } & \multirow{2}{*}{\multicolumn{2}{|c|}{ Total }} & \multirow{2}{*}{$p$-value } \\
\hline & \multicolumn{2}{|c|}{$\mathrm{Ya}$} & \multicolumn{2}{|c|}{ Tidak } & & & \\
\hline & $\mathrm{F}$ & $\%$ & $\mathrm{f}$ & $\%$ & $F$ & $\%$ & 0,000 \\
\hline a. General & 53 & 88,3 & 5 & 21,7 & 58 & 69,9 & \\
\hline b. Regional & 7 & 11,7 & 18 & 78,3 & 25 & 30,1 & \\
\hline Total & 60 & 100 & 23 & 100 & 83 & 100 & \\
\hline
\end{tabular}

\section{PEMBAHASAN}

1. Karakteristik responden di Ruang Pemulihan RSUD Banyumas.

Berdasarkan hasil penelitian menunjukkan bahwa sebagian besar responden berumur 36-46 tahun sebanyak 51 responden $(61,4 \%)$. Usia responden dalam penelitian ini termasuk dalam kategori usia dewasa akhir. Depkes (2009) menjelaskan bahwa masa dewasa akhir yaitu 36-45 tahun. Menurut Khasanah (2017) bahwa usia dewasa akhir adalah suatu tahapan memasuki usia menjadi tua.
Proses yang dialami seseorang ditandai dengan perubahan secara fisik serta psikis.

Berdasarkan analisis data penelitian menunjukkan bahwa responden paling banyak berjenis kelamin laki-laki sebanyak 52 responden $(62,7 \%)$.

Berdasarkan hasil penelitian menunjukkan bahwa responden paling banyak adalah pendidikan pendidikan SMA/SMK sebanyak 39 responden $(47,0 \%)$. Pendidikan merupakan faktor penting dalam menentukan perilaku seseorang dalam menjaga kesehatannya. Pendidikan yang tinggi lebih cenderung untuk mudah dalam menyerap dan 
memahami suatu permasalahan kesehatan. Menurut Amalia (2009) bahwa jenjang pendidikan seseorang memegang peranan penting dalam kesehatan masyarakat. Pendidikan seseorang yang rendah menjadikan mereka sulit memahami akan pentingnya higyene perorangan dan sanitasi lingkungan untuk mencegah terjangkitnya penyakit menular.

Perilaku yang sehat menjadikan seseorang terhindar dari berbagai penyakit baik kronis maupun akut. Hal ini secara tidak langsung dapat mencegah tindakan atau penangan kesehatan dengan operasi. Menurut Notoatmodjo S. (2012) bahwa pengetahuan yang tinggi tentang kesehatan, dapat meningkatkan pola pikir terhadap konsep sehat dan sakit. Oleh karena itu, akan menjadikan seseorang bagaimana berperilaku dalam meningkatkan derajat kesehatan.

2. Jenis anastesi di Ruang Pemulihan RSUD Banyumas.

Berdasarkan hasil penelitian menunjukkan bahwa sebagian besar responden mendapatkan anastesi general sebanyak 58 responden $(69,9 \%)$. General anestesi merupakan teknik yang banyak dilakukan pada berbagai macam prosedur pembedahan (Islami, 2012). Menurut Nurkacan (2013) bahwa jenis anastesi menentukan kejadian hipotermi. Terdapat perbedaan angka kejadian antara pasien yang mendapat anastesi spinal dengan pasien yang mendapat anastesi umum. Kejadian hipotermi pada anastesi umum lebih besar daripada anastesi spinal. Perpindahan panas antara pasien yang menjalani anastesi umum lebih cepat mengalami penurunan suhu jika dibandingkan anastesi spinal.

Harahap (2014), menyatakan general anestesi memiliki pengrauh dalam menghambat proses adaptasi dan mengganggu fungsi termoregulasi pada sistem mekanisme fisiologi tubuh.

3. Kejadian hipotermi di Ruang Pemulihan RSUD Banyumas.

Berdasarkan hasil penelitian menunjukkan bahwa sebagian besar mengalami hipotermi sebanyak 60 responden (72,3\%). Pada dasarnya kejadian hipootermi yang terjadi di ruang pemulihan tidak dapat dihindari bagi pasien. Hipotermia merupakan suatu kedaan dimana korban dalam keadaan dingin atau suhu badan korban menurun karena lingkungan yang dingin. Bila turun $1-2^{\circ} \mathrm{C}$ tingkat hipotermi tergolong masih ringan. Namun, jika turun lebih dari $3^{\circ} \mathrm{C}$ maka tingkat hipotermi tergolong berat Huang et. al. (2015).

Hipotermi pada pasien operasi juga dapat disebabkan oleh kondisi lingkungan / suhu ruangan kamar operasi. Hasil penelitian Listiyanawati (2018) menunjukkan bahwa pasien post operasi dapat mengalami hipotermi dikarenakan kondisi suhu ruangan yang rendah.

Menurut Hujjatulislam (2015) bahwa hipotermi yang dialami pasien post operasi dapat terjadi karena agen dari obat general anestesi menekan laju metabolism oksidatif yang menhasilkan pasa tubuh sehingga menganggu regulasi panas tubuh. Smeltzer, et al, 2013 menjelaskan bahwa perubahan fisiologis pada tubuh pasien yang menjalani pembedahan dapat berupa penurunan suhu tubuh atau hipotermi. Pasien pasca bedah yang mengalami hipotermi akanmenggigil sebagai mekanisme kompensasi tubuh terhadap hipotermi.

4. Hubungan jenis anastesi dengan kejadian hipotermi di Ruang Pemulihan RSUD Banyumas.

Berdasarkan hasil penelitian menunjukkan hasil uji chi square diperoleh $\mathrm{p}$ value sebesar $0,000(\mathrm{p}<0,05)$, artinya ada hubungan jenis anastesi dengan kejadian hipotermi di Ruang Pemulihan RSUD Banyumas. Hasil didukung penelitian Harahap (2014) bahwa jenis anastesi berhubungan dengan kejadian hipotermi di ruang pemulihan.

Hasil analisis statistik menunjukkan bahwa dari 58 responden yang mendapatkan anastesi general sebagian besar mengalami hipotermi sebanyak 53 pasien sedangkan pasien yang mendapatkan anastesi regional sebanyak 25 pasien sebagian besar tidak mengalami hipotermi sebanyak 18 responden.

Nurkacan (2013) menjelaskan bahwa jenis anastesi menentukan kejadian hipotermia. Ada perbedaan angka kejadian antara pasien yang mendapatkan anastesi 
spinal dengan pasien anastesi umum. Kejadian hipotermi pada anastesi umum lebih besar daripada anastesi spinal.

Hasil penelitian ini juga didukung oleh hasil penelitian Huang et. al. (2015) menunjukkan bahwa faktor anasetesi $25,7 \%$ merupakan faktor penyebab hipotermi pada pasien anasetesi dan 74,3\% dipengaruhi oleh faktor lainnya seperti umur, durasi dan suhu ruangan.

\section{KESIMPULAN}

1 Pasien paling banyak responden berumur 36-46 tahun, sebagian besar berjenis kelamin laki-laki dan. pendidikan paling banyak adalah pendidikan SMA/SMK

2 Pasien sebagian besar responden mendapatkan anastesi general.

3 Pasien sebagian besar mengalami hipotermi.

4 Terdapat hubungan jenis anastesi dengan kejadian hipotermi di Ruang Pemulihan RSUD Banyumas

\section{DAFTAR PUSTAKA}

Amalia. (2009). Hubungan Antara Pendidikan, Pendapatan Dan Perilaku Hidup Bersih Dan Sehat (PHBS) Pada Pedagang Hidangan Istimewa Kampung (Hik) Di Pasar Kliwon Dan Jebres Kota Surakarta. Skripsi. Universitas Muhammadiyah Surakarta.

Hanifa. (2017). Hubungan Hipotermi Dengan Waktu Pulih Sadar Pasca General Anestesi Di Ruang Pemulihan RSUD Wates. Naskah Publikasi. Politeknik Kesehatan Kementerian Kesehatan

Harahap. (2014). Angka Kejadian Hipotermia dan Lama Perawatan di Ruang Pemulihan pada Pasien Geriatri Pascaoperasi Elektif Bulan Oktober 2011-Maret 2012 di Rumah Sakit Dr. Hasan Sadikin Bandung. Jurnal Anestesi Perioperatif, 2 (1)

Huang W., Lu Yang, Chan-Yan H., Zhi-Bin Z., Zhi-Shuang W., Guan-Rong Z., Ke-Xuan L., (2015). Risk factors for hypothermia in patients under general anesthesia: Is there a drawback of laminar airflow operating rooms? A prospective cohort study.International Journal of Surgery 21, 14-17.
Hujjatulislam. (2015) Perbandingan Antara Penggunanan Asam Amino dan Ringer Lactat Terhadap Penurunan Suhu Inti Pasien yang menjalani Operasi Laparatomi Ginekologi dengan Anasetsi Umum. Jurnal Perioperatif, 3 (3): 139-45.

Kemenkes RI. (2013). Standar Pelayanan Minimal Rumah Sakit. Jakarta : Kemenkes

Khasanah. (2017). Periodesasi Perkembangan Dewasa Akhir (Perkembangan Fisik, Psikis, Sosial, Keagamaan Dalam Periode Kehidupannya). Artikel Ilmiah. Universitas Muhammadiyah Sidoarjo

Listiyanawati. (2018). Efektifitas Selimut Elektrik dalam Meningkatkan Suhu Tubuh Pasien Post Seksio Sesarea yang Mengalami Hipotermi. Jurnal Kesehatan Vokasional, 3 (2).

Notoatmodjo S. (2012). Promosi kesehatan dan ilmu perilaku. Jakarta: Rineka Cipta.

Smeltzer, S.C. \& Bare, B.G. (2013). Buku Ajar Keperawatan Medikal Bedah Brunner \& Suddarth, edisi 8. Jakarta : EGC. 